Mitchell O. Hopkins

\title{
Romania's Civil Society and its Moral Underpinnings: The Symbolic Discourse of a Post-Socialist State
}

U sing Katherine Verdery's definition of civil society as the population of a social space between the everyday household and the state, the paper looks at how such events as the rise and fall of the USSR, the advent of the EU, or even the workings of the Ottoman Empire have affected the discussion and development of civil society in Romania.

\section{Introduction}

Civil society, it is often conceived of as a high-minded ideal that is connected to democracy, community, and participation. The discourse surrounding civil society is highly contextual. In the USA it is virtually equated with the presence of NGOs and in Albania it is equated with democracy itself (Paley 482). Johnson and Wright give a fairly typical definition of civil society: a network of free associations where people can care for one another, build their community, exercise influence on a government, and stimulate local commercial activity (143). No one consistently opposes civil society's development, partly because its' definition is vague and highly theoretical. However, Carothers warns against such optimistic definitions, explaining that nefarious organizations such as the Russian mafia (1999:20) or the skinhead movement in Hungary are also part of civil society, although sometimes are renamed "uncivil society" as an addendum (Stewart 565). Katherine Verdery has broadly defined civil society as the population of a social space between the everyday household and the state (1991:432). Working 
from Verdery's definition, this essay will elucidate how Romania's history has impacted the society's moral tendencies, shaping their conceptions of nationhood, democracy, and Europe. These three master-symbols are interrelated, each influencing the way that Romanians conceive of civil society.

\section{Analysis}

Civil society, with its attractive combination of democratic pluralism and state regulation, is often seen as the answer to postsocialist problems (Kumar 375). In Romania and other post-socialist nations, the social space that Verdery speaks of was systematically destroyed by authoritarian regimes whose goal was to absorb all sources of social allocation into the party apparatus. The state artificially filled this space with party-led unions and community organizations and disabled all independent groups. This worked to alienate Romanians from one another and from the political sphere, reducing their tendency for initiative and their capacity to make their own plans (Verdery 1991:432-433). During Ceauşescu's regime, which marked the last 24 years of Soviet control, the phrase civil society vanished from all official and colloquial use, contributing further to Romania's slow post-revolution development of civil society when compared with neighboring countries (Grunberg 310). The first authentic civil organizations, such as SLOMR and the Goma Circle (Verdery 1991:432) began in the 1970s as anti-political and anti-state dissident movements. Working from Verdery's definition, black markets active under party rule can also be seen as germinal activities of civil society because they were something other than state or household (Gal and Kligman:14). Since these organizations only held the one collective goal of opposing the state, they did not contribute to a pluralism of opinions or interests. Once Ceauşescu's regime had collapsed, these broadly based solidarity networks could 
do little to foster nation building or democratization. Indeed, Carothers has raised the criticism that attempts to develop civil society in Romania have focused too much on broad, high-minded ideals and have understated the importance of more popular forms such as labour unions, professional associations, and religious institutions. He also points out that small issue-specific associations have been popular at local levels (1996:73). While it is true that authoritarian rule dampened the upbringing of Romania's civil society relative to its western neighbors, civil society is still a useful concept when looking at the broadening space between household and state since the 1970s. Romanians viewed these alternative networks of power in many different ways, bringing hope to some and fear to others.

It is vital to account for morality when discussing people's conceptions of politically loaded terms. It affects people's conceptions by distinguishing between what is "good" and "bad," "right" and "wrong," etc. (Verdery 1996:184) There are many potential sources of moral authority in any given society. The conditions that Romanians lived in under communism have had a great effect on what they believed is good for Romania, thus structuring their conceptions of political symbols. This has more recently been manifest as anticommunist sentiments, since politicians try to distance themselves, at least on the surface, from the pre-revolution leadership. The sudden illegitimacy of socialist rhetoric forced parties to look for alternative symbols to build their platform, the main two being nation and civil society. There was, however, an underlying continuity with socialist values such as equality and welfare, which actually lead to a fairly popular anti-reform movement (Verdery 1996:110). One can see how important it was for politicians to frame their goals carefully within the bounds of those moral and symbolic values that Romanians found important. In addition, Verdery has 
developed the notion of "moral capital," which has a large impact on one's authority in the political sphere (Verdery 1996:108). Those who suffered under Ceauşescu's regime usually gained a higher status after the revolution. Iliescu, his successor, kept no secrets about the way his career apparently suffered when he refused to abide by party policy. Bădescu and Sum have made another interesting observation about the way that pre-socialist empires can also have an effect on civil society. They found that values of trust, cooperation, membership, and community to be relatively more widespread in Transylvania, a former part of the Hungarian Empire (123). Their argument states that, in addition to greater socioeconomic development, the empire's rich civic tradition and dense social networks contributed to this regional disparity (130). The moral values outlined by Bădescu and Sum therefore contributed to a disparity in civic participation. Romania's history, both socialist and pre-socialist, had a great impact on the different actors' moral political outlook when civil society began to evolve after December of 1989.

Although the growing strength of opposition parties was creating more of a social space for civil society to operate in, the relative weakness of civil society in Romania led to a scholarly fear that communist tyranny would be replaced with the majority tyranny of anti-communist nationalism (McIntosh, Iver and Abele 940). Civil society in Romania was still essentially seen as something anti-state and had always been pitted as something contradictory to the government. After the revolution civil society was still closely allied with the opposition parties and parties together sought to legitimate themselves on moral grounds. These include morals set by the communist party as well as older national values (Verdery 1996:107). Nationalist practices can also be seen as building on the remnants of old socialist moral claims, specifically solidarity (Verdery 1996:127). 
This subsequently developed into a resistance to the social division and potential inequality of civil society; since civil society is ideally a sphere of plurality and competing values, it is difficult to reconcile with the tradition of solidarity.

Ethnic nationalism eventually led to a rebranding of the entire concept of civil society (Benezin 305). The opposition faced a dilemma: should they "ride nationalism to victory or uphold civic values?" (Verdery 1996:116). In light of the popularity of nationalism and the widespread view that civil society was divisive rather than unifying, opposition parties were forced to modify their conception of civil society. Instead of being the realm of competing politics that is central to democracy, the symbol civil society became, at least in the opposition's discourse, a unified moral realm that was completely separate from politics (127). Thus nationalism overshadowed the original civic sentiments in the opposition's platform. Another reason civil society appeared incompatible with nationalism was the conflict between minority rights and national unity. Typically civil society endorsed the recognition of group rights for minorities, such as the $10 \%$ Hungarian minority of Transylvania. This was an affront to most Romanian nationalist voters and proved lethal in the elections (Verdery 1996:121). And so in Verdery's words,

...the pressure of a certain historically constituted discourse and of it's master-symbol 'nation,' compels all other political actors in Romania to 'nationalize' their political instruments - and in so doing, to strengthen 'nation' as a political symbol even further (129).

In Romania the homogenizing discourse of nationalism overcame the pluralizing discourse of civil society. In this manner, moral claims of unity or pluralism have structured the way people think about civil society. 
Closely linked to Romania's nationalist sentiments are Romanian's conceptions of democracy. Even though he had only a slim majority, Ceaşescu's successor Iliescu operated on a platform of democratic consensus. In this conception of democracy, people who do not agree with the leadership are expected to accept its decisions anyway, giving way for the common good of the nation (Verdery 1996:112). This view is grounded in the old communist moral code. Dissidents were often labeled as ambitious traitors or antiRomanians; "We see that the most perilous politics (draped in the garb of democracy, naturally!) comes from the opposition publications... all these people were traitors before and still are today" (113). The opposition responded by defining themselves as the real defenders of democracy and labeling the socialist-nationalist leadership as anti-democratic. Their definition of democracy was a system of institutionalized competition and compromise. Just like civil society, democracy was supposed to be, in their view, a realm of free politics, which was by nature morally superior to a unilateral approach. Iliescu disabled much of civil society by inculcating his own moral views towards democracy and monopolizing the use of this key symbol.

Politicians often showed animosity towards civil society and the NGO's, whose proliferation would be, in their view, a brand of decentralization. To be sure, before 1989 civil society was concerned with the self-defense and self-management of society and ignored the state's authority as much as possible (Kumar 386). It could be seen as a sort of horizontally integrated, parallel society. Civil society organized itself in this way mostly because the head-on engagement of the state would be suicidal under party rule. Since Ceauşescu incarcerated many of civil society's supporters in the intellectual circle, some of them gained moral capital after the revolution as defenders of national values and civil society. Now that Romania 
was democratic, civil society movements were free to challenge the government openly and in the following years they persistently sided with the opposition. The government's pervasive distrust of civil society can be seen in the NGO sponsorship law, which allows only $5 \%$ of an NGO's income to go untaxed (Johnson and Wright 152), practically putting them in the same category as commercial businesses.

According to Carothers, the link between civil society and the political opposition is becoming less prevalent, and NGO's are starting to align themselves more contextually (Carothers 1996:66). The popular belief that the opposition was blocking Romania's progress and dividing the nation led the civil society movement to delink from the opposition and undergo an anti-political reinterpretation (Grunberg 310). Due in part from public distrust of the government left over from the communist era, politics was seen as something separate and shameful. Many NGO directors claim that their organization is not political; unaware that simply being a member of an NGO is a political act. Grunberg has pointed out that this disdain for politics may be inhibiting NGOs from addressing the root causes of problems, content to merely address symptoms here and there. Evidently, the moral code that a person brings to bear on terms like democracy and civil society can affect the way that they act towards parties, NGOs, and society as a whole.

Another master-symbol identified by Verdery is Europe. This symbol has been widely used in the discourse of nationalism, democracy, and civil society in Romania. Building civil society can be seen as a return to Romania's natural place in Europe and claims like this often include Romania as the placeholder of the glorious Roman Empire. Others see Europe as an assimilating neocolonial threat, one that opposes the "Romanianness" and unity of the nation. Ceauşescu fostered an indigenous approach that tended to reduce the 
importance of Europe and civil society (Verdery 1996:109). The nationalists went much further, calling those opposition parties who talk of Europe "antipatriotic, servants of 'foreign powers' (i.e., Europe, Hungary), lackeys of the American Embassy, and traitors who aim to 'sell the country' and should be expelled from Romania's new democracy" (Verdery 1996:111). Consequently they prefer to shore up Romanian nationalism by referring to Dacian roots, comparing Roman expansionism to Europe's similar tendencies of today. In response to accusations of European anti-patriotism, the opposition has accused Iliescu being suspiciously close to Gorbachev and pushing the nation back into the arms of Russia;

Is this in the national interest of Romanians, when all our greatest misfortunes have not come from the West but from the East? Can it be in the national interest to push the country into the arms of the Russians, who have never known any relation of 'collaboration' except to subjugate the weaker partner? (Verdery 1996:114).

In addition, appearing too European or too cosmopolitan has become a problem for NGOs as well. The public has ridiculed NGOs for holding western views; and many have failed in the eyes of Romanians (Grunberg 324). The Bucharest-based NGO "Gender" has predictably faced derision because its name does not even have an equivalent translation in Romanian. Given that civil society is often seen as an import from Europe, one's moral view of Europe as either an aid to Romania's failing living standards or a threat to Romanian identity can positively or negatively impact one's view of civil society.

The importance of the symbol Europe was obviously reinforced when the issue of Romania's entrance in to the EU came onto the scene. In many respects, Romania was seen as an "unwelcome bastard" by the EU, being infantilized by its Western relatives and 
being required to undergo a probationary period of "Europeanization" (Borneman and Fowler 496). The opposition pointed to Romania's drop in living standards since the 80s to the lowest in Europe and accused the government of sabotaging Romania's credibility in the eyes of the West (Verdery 1996:124). Despite the hostility towards Europeanization in the official discourse, the government petitioned the Council of Europe for admittance in 1993. The complexity of the symbol of Europe was illustrated by the in-party fighting between hardline nationalists and those supporting European integration that emerged during this period (Verdery 1996:126).

\section{Conclusion}

The key symbols of Europe, nation, and civil society can be observed in Krista Harper's interesting case study about the development of environmental movements surrounding the industrialization of the Danube and Tisza rivers. In the 1980's the growing devastation of the Danube and surrounding landscape contributed to the public's first introduction to civil society (Harper 229). In 2000 a foreign-owned mining operation in Baia Mare, Romania, spilled thousands of tons of cyanide and heavy metals into Danube's largest tributary, the Tisza, affecting several countries. This sparked public awareness of international social capital and environmental solidarity. These movements also evoked binaries, namely civil society versus the state, but also socialism versus democratization and nationalism versus international solidarity and "Europeanness" (222). These citizens transcended nationalist boundaries; dissident environmentalists from different countries were pitted against the central planners of the state, eventually growing into an epic social movement in a transitional period. The media coverage of the events got the attention of the West as well as 
larger NGOs such as Greenpeace (229). Amid all the drama were worries about Hungarian and Romanian ascension into the EU. Hungary declined to launch an international lawsuit for fear that it would further harm their chances of entry. There was a collective cry for more public involvement in decision making, which opened a space for civil society to operate in. The event highlighted the importance of civic organization and resistance to developments that endanger people and the environment. One way of interpreting the event is via the binary of democracy versus socialism. Eastern leaders have often favored monumental "Stalinist" industry, overriding natural law to the point of irrationality (230). The cry for public involvement could then refer to both democratization and civic involvement. For instance, Harper also explains that, instead of civil society being opposed to the state, in the modern world civil society is more frequently on the side of the state, challenging the rationality of markets and bidding for more state regulation. "[This] is the perfect example of ecocolonialism," the president of the Tisza Club stated, "taking advantage of the lack of regulations and unemployment..." (230). The Danube and Tisza disasters and related environmental movements are modern-day examples of how the master symbols nationalism, democracy, and Europe can be challenged and redefined, resulting from specific event and a subsequent change in moral outlook.

In conclusion, the working definition of civil society is highly contextual and varies from nation to nation, and even from region to region. Journalists, scholars, and politicians love to talk about civil society and different ways to encourage its growth, but a specific analytical definition is rarely lent to the discussion. Romania's particular historical and contemporary events impacted the society's moral and worldview, and consequently Romanian's own experiences of civil society. Romanian's world outlook also informed and 
structured their conceptions of master symbols such as nation, democracy, and Europe. These three symbols played significant parts in determining the route civil society has taken in Romania and the way it is conceived of in various discourses. Although many democracies, such as Spain and Albania (Carothers 21), function very competent without strong civil societies, Romanian civil society continues to become more westernized and will continue to be a significant force, as one can see from the flurry of participation around the Tisza and Danube disasters. It will be interesting to see how Romania's historical and political configuration translates western discourses and makes sense of events to come.

\section{Works Cited}

Bădescu, Gabriel and Paul E. Sum. "Historical Legacies, Social Capital and Civil Society: Comparing Romania on a Regional Level." Europe-Asia Studies 57.1 (2005): 1-169. Print.

Berezin, Mabel. "Minority Rights and Majority Rule: Ethnic Tolerance in Romania and Bulgaria." Social Forces 73.3 (1995): 789-1196. Print.

Borneman, John and Nick Fowler. "Europeanization." Annual Review of Anthropology 26 (1997): 1-686. Print.

Carothers, Thomas and William Barndt. "Civil Society." Foreign Policy 177 (1999-2000): 1-174. Print.

Carothers, Thomas. Assessing Democracy Assistance: The Case of Romania. Washington, D.C.: Carnegie Edowment for International Peace, 1996. Print.

Gal, Susan and Gail Kligman. "Introduction." Reproducing Gender: Politics, Publics, and Everyday Life After Socialism. Princeton, NJ: Princeton University Press, 2000. 3-20. Print.

Grunberg, Laura. "Women's NGOs in Romania." Gal, Susan and Gail Kligman. Reproducing Gender: Politics, Publics, and Everyday Life after Socialism. Princeton NJ: Princeton University Press, 2000. 307-336. Print. 
Harper, Krista. "'Wild Capitalism" and "Ecocolonialism": A Tale of Two Rivers." American Anthropologist 107.2 (2005): 183-320. Print.

Johnson, Alice K. and Barbara T. Wright. "Civil Society in Romania: An Evolving Partnership." Burbidge, John. Beyond Prince and Merchant: Citizen Participation and the Rise of Civil Society. New York: Pact Publications, 1998. 143-160. Print.

Kumar, Krishan. "Civil Society: An Inquiry into the Usefulness of an Historical Term." The British Journal of Sociology 44.3 (1993): 375-562. Print.

McIntosh, Mary E., et al. "Minority Rights and Majority Rule: Ethnic Tolerance in Romania and Bulgaria." Social Forces 73.3 (1995): 789-7796. Print.

Paley, Julia. "Toward an Anthropology of Democracy." Annual Review of Anthropology 31 (2002): i-xx+1-578. Print.

Sampson, Steven. "Is There an Anthropology of Socialism?" Anthropology Today 7.5 (1991): 16-19. Print.

Verdery, Katherine. What Was Socialism, and What Comes Next? Princeton NJ: Princeton University Press, 1996. Print.

Mitchell O. Hopkins is an independent researcher and alumnus of the University of Alberta. His interests include social anthropology, cultural studies, and aesthetics.

Contact: mohopkin@ualberta.ca 